\title{
Disease status and combined effect of biological control and organic amendments in managing stem rot disease of carnation caused by Rhizoctonia solani
}

\author{
S. Sharma* and S. Chandel \\ Department of Plant Pathology, Dr. Y. S. Parmar University of Horticulture and Forestry, Nauni, Solan-173230 \\ (H.P.), INDIA \\ *Corresponding author. E-mail: sushsharma1987@gmail.com
}

Received: August 07, 2015; Revised received: May 07, 2016; Accepted: August 27, 2016

Abstract: The present study was carried out to know the effect of different soil amendments and biological control on disease incidence, different plant growth and flower parameters. Incidence of stem rot was found serious in almost all the locations surveyed, maximum incidence being recorded at Berthin (33.7\%) in district Bilaspur followed by Rajgarh (32.0\%), Solan (27.3\%) and Matnali $(27.1 \%)$ in district Sirmour in contrast to lowest incidence $(11.2 \%)$ of stem rot in Shimla. Integration of Melia azedarach seed (powder) along with Trichoderma viride as well as Neem cake with $T$. viride and $T$. harzianum gave maximum reduction $(75.67 \%)$ in disease incidence of stem rot with minimum disease incidence $(6 \%)$, in comparison to 24.67 per cent in control followed by Bacillus subtilis + Melia azedarach (8\%). These treatment also improved the plant growth and flower quality parameters by giving the average plant height to $82.32 \mathrm{~cm}, 81.05 \mathrm{~cm}$, stem length $(76.64 \mathrm{~cm}, 75.91 \mathrm{~cm})$, number of flowers per plant $(3.79$, $3.68)$, flower size $(7.20 \mathrm{~cm}, 7.17 \mathrm{~cm})$ and took less number of days to first flowering. Disease management practice alone is not sufficient until integrated with other components, as disease is a complex phenomenon governed by many factors. The integration of effective management practices such as plant oils, botanicals and antagonists would be important for the successful management of plant diseases, thus showing its practical applicability in field in mitigating the losses caused by disease in carnation.

Keywords: Biological control, Carnation, Disease incidence, Integrated disease management, Stem rot

\section{INTRODUCTION}

Among different ornamental crops, carnation (Dianthus caryophyllus L.) is one of the major cut flowers of the world and ranks $7^{\text {th }}$ in world flower market (Evans, 2008). It belongs to the family caryophyllaceae and is native to Mediterranean region.Carnation is subjected to be attacked by number of fungal, bacterial and viral pathogens which result in huge loss of planting material and quality flowers. The fungus (Rhizoctonia solani) is capable of inducing stem rot in number of crops and is frequently prevalent and considered damaging disease in all parts of the world such as it causes $30-50 \%$ losses in potato, soybean and sugarbeet (Kurzawinska, 2008).

Carnation is a most important commercial crop under protected cultivation in Himachal Pradesh and owing to the huge losses caused by the disease and the importance of the flower crops in national and international market attempts were made to use a consortium of biological agents to get persistent control of plant pathogens. The fungus, $R$. solani is a major pathogen of most of the agricultural crops both in greenhouse and field conditions in the warm ornamental growing areas of the world. The fungus is essentially a soilborne in nature which inflicts heavy crop losses under favourable conditions. The management of this disease is difficult owing to the long saprophytic survival ability of pathogen in soil. Fungicidal application as seed or soil treatment however, has been found to be ineffective against these pathogens as the propagules are capriciously distributed in the soil and often beyond the reach of chemicals. Biological control therefore, holds promise as a strategy for disease management and it is environment friendly too. Antagonists fungi especially Trichoderma spp. and the bacteria, fluorescent Pseudomonas have been widely used against a number of phytopathogens (Rini and Sulochana, 2007). In recent years, attempts were also made to use a consortium of integration of organic amendment and biological agents to get persistent control of plant pathogens (Tripathi et al., 2008). Keeping this in view and the growing importance of integrated practices, the present study was carried out with the objective to record the incidence of stem rot in major carnation growing areas of H. P. and integration of organic amendment and biological control practices against stem rot pathogen to see their impact on disease and growth 
parameters.

\section{MATERIALS AND METHODS}

Disease survey: A regular surveys of different carnation growing areas in Nauni, Matnali, Rajgarh, Namhol, Ghanatti and Berthin of Solan, Sirmour, Bilaspur and Shimla districts of Himachal Pradesh were carried out to record the incidence of stem rot in carnation under protected environment. The per cent disease incidence was calculated by the formula given as:

Disease Incidence $(\%)=$ Number of Diseased Plants / Total Number of Plants Observed $\times 100$

Evaluation of organic amendment: An experiment pertaining to organic amendment evaluation was laid out in C R D (Completely randomized design) under pot culture with four soil amendments viz., neem cake (Azadirachta indica L.), darek seeds (powder) (Melia azedarach L.), cotton cake and mustard oil cake including control treatment which were incorporated into the soil @2.0\% (wt/wt) and mixed thoroughly in the upper $15 \mathrm{~cm}$ soil layers one week before planting of the one month old rooted cuttings of carnation 'Rubesco' variety. The soil used was pre-sterilized by formalin $(5 \%)$ and artificially inoculated with the test pathogen@5 g (wt/wt) basis a week prior to addition of soil amendments.In total three carnation cuttings of variety 'Rubesco' were planted in each pot. Pots without any amendments were kept as control. Each treatment was replicated four times and data pertaining to disease incidence $(\%)$, different plant growth and flower characters were recorded.

Effect of fungal and bacterial antagonists: Five different species of native fungal antagonist species of Trichoderma viz., T. harzianum, T. hamatum, T. viride, T. polysporum and T. virens and two bacterial antagonistic species namely Bacillus subtilis and Pseudomonas fluorescens were procured from the Department of Plant Pathology and Department of Basic Science of U.H.F. Nauni, Solan (H.P.). Fungal antagonists (Trichoderma spp.) were tested for their antagonistic activities against stem rot by dual culture technique
Table 1. Incidence of stem rot of carnation in different parts of Himachal Pradesh during 2012-13.

\begin{tabular}{lcc}
\hline District & Locality & Disease incidence (\%) \\
\hline \multirow{3}{*}{ Solan } & Solan & 27.3 \\
& Nauni & 26.1 \\
& Mean & 26.7 \\
\multirow{3}{*}{ Sirmour } & Rajgarh & 32.0 \\
& Matnali & 27.1 \\
& Mean & 29.5 \\
\multirow{3}{*}{ Bilaspur } & Namhol & 29.3 \\
& Berthin & 33.7 \\
\multirow{3}{*}{ Shimla } & Mean & 31.5 \\
& Ghanatti & 11.2 \\
\hline
\end{tabular}

(Huang and Hoes, 1976). Culture discs (4 mm diameter) of each of antagonists and the pathogen were taken from margin of their vigorously growing culture and transferred aseptically to solidified PDA (Potato Dextrose Agar) contained in Petri plates $(90 \mathrm{~mm})$ on the opposite side facing each other at a distance of $1 \mathrm{~cm}$ from the margin of the plate. The Petri plates containing only culture of the pathogen served as control. The experiment was laid out in CRD and each treatment was replicated thrice and the Petri plates were incubated at $27 \pm 1^{\circ} \mathrm{C}$ in BOD incubator. The colony diameter of test fungus was recorded till the control plates achieved full growth of the test fungus. The antagonistic activity of Bacillus subtilis and Pseudomonas fluorescens against the stem rot pathogen was observed by streak plate method (Utkhede and Rahe, 1983). The Petri plates containing sterilized PDA were streaked at the centre with 48 hours old colonies of bacteria with the help of bacterial loop. Mycelial bit (4 mm diameter) of the test pathogen was placed on opposite sides of the streak at a distance of $1 \mathrm{~cm}$ from the margin of the plate. Petri plates without bacterial streak served as control for comparison. Each treatment was replicated thrice under Completely Randomized Design (CRD) and incubated at $27 \pm 1^{\circ} \mathrm{C}$ in BOD incubator. Per cent mycelial inhibition in the growth of test pathogen was calculated.

Table 2. Effect of organic amendments on incidence of stem rot, plant growth and flower characters.

\begin{tabular}{|c|c|c|c|c|c|c|c|c|}
\hline Treatment & $\begin{array}{c}\text { Conc. } \\
(\%)\end{array}$ & $\begin{array}{l}\text { Disease inci- } \\
\text { dence }(\%)\end{array}$ & $\begin{array}{c}\text { Disease } \\
\operatorname{control}(\%)\end{array}$ & $\begin{array}{c}\text { Plant } \\
\text { height } \\
\text { (cm) }\end{array}$ & $\begin{array}{c}\text { Stem } \\
\text { length } \\
(\mathrm{cm})\end{array}$ & $\begin{array}{l}\text { No. of days taken } \\
\text { for } 1^{\text {st }} \text { flowering }\end{array}$ & $\begin{array}{c}\text { No. of } \\
\text { flowers / } \\
\text { plant }\end{array}$ & $\begin{array}{l}\text { Flower size } \\
(\mathrm{cm})\end{array}$ \\
\hline Neem cake & $2 \%$ & $24.37(22.13)$ & 48.51 & 50.33 & 42.49 & 145.7 & 3.20 & 5.95 \\
\hline Cotton cake & $2 \%$ & $30.00(30.75)$ & 36.61 & 46.73 & 40.00 & 150.0 & 2.41 & 5.87 \\
\hline $\begin{array}{l}\text { Melia azedarach } \\
\text { (seed powder) }\end{array}$ & $2 \%$ & $15.62(14.62)$ & 66.99 & 56.73 & 49.83 & 145.9 & 3.33 & 5.95 \\
\hline Mustard cake & $2 \%$ & $27.50(24.75)$ & 41.89 & 47.91 & 40.91 & 151.9 & 2.08 & 5.54 \\
\hline Control & - & $47.33(40.01)$ & - & 43.00 & 36.33 & 155.0 & 2.00 & 4.83 \\
\hline $\mathrm{CD}_{(0.05)}$ & & (3.70) & & 2.21 & 1.98 & 1.97 & 0.46 & 0.36 \\
\hline
\end{tabular}

Figures in parentheses are arc sine transformed values 
Table 3. Effect of antagonists on incidence of stem rot, plant growth and flower characters of carnation.

\begin{tabular}{lcccccccc}
\hline Antagonists & $\begin{array}{c}\text { Conc. } \\
(\boldsymbol{\%})\end{array}$ & $\begin{array}{c}\text { Disease inci- } \\
\text { dence } \mathbf{( \% )}\end{array}$ & $\begin{array}{c}\text { Disease } \\
\text { control } \\
(\boldsymbol{\%})\end{array}$ & $\begin{array}{c}\text { Plant height } \\
(\mathbf{c m})\end{array}$ & $\begin{array}{c}\text { Stem length } \\
(\mathbf{c m})\end{array}$ & $\begin{array}{c}\text { No. of days } \\
\text { taken for 1 } \\
\text { stowering }\end{array}$ & $\begin{array}{c}\text { No. of } \\
\text { flowers / } \\
\text { plant }\end{array}$ & $\begin{array}{c}\text { Flower size } \\
(\mathbf{c m})\end{array}$ \\
\hline T. viride & $1 \%$ & $17.33(24.57)$ & 57.02 & 71.80 & 65.57 & 133.20 & 3.53 & 6.24 \\
T. hamatum & $1 \%$ & $26.67(31.08)$ & 33.87 & 67.20 & 64.27 & 133.20 & 3.47 & 6.21 \\
T. harzianum & $1 \%$ & $20.00(26.49)$ & 50.40 & 69.40 & 60.60 & 137.60 & 3.27 & 5.82 \\
T. polysporum & $1 \%$ & $37.33(37.66)$ & 7.43 & 62.80 & 56.46 & 143.05 & 2.87 & 5.65 \\
Bacillus subtilis & $1 \%$ & $28.00(31.91)$ & 30.57 & 66.88 & 59.28 & 137.80 & 3.20 & 5.76 \\
Control & & $40.33(40.01)$ & 0 & 51.55 & 50.28 & 149.67 & 2.35 & 5.37 \\
CD $_{(0.05)}$ & & $(3.70)$ & & 5.27 & 5.21 & 10.79 & 0.72 & 0.37 \\
\hline
\end{tabular}

Figures in parentheses are arc sine transformed values

Combined effect of bio-control agents and organic amendments for the management of stem rot of carnation: In this experiment, treatment of carnation rooted cuttings with bio-control agents was combined with organic amendments for effective management of the carnation stem rot. Soil amendments viz., neem cake, Melia azedarach (seeds powder)@ $1 \mathrm{Kg} / \mathrm{m}^{2}(10$ tonnes/ha) applied in beds (1m x $1 \mathrm{~m})$ and mixed thoroughly in the soil in upper $15 \mathrm{~cm}$ layer and irrigated till saturation level and left for decomposition for two weeks before planting the carnation cuttings.

The treatments of four bioagents Trichoderma viride, T. harzianum, T. hamatum and Bacillus subtilis in different combination viz., (T. viride + neem cake, $T$. viride + Melia azedarach seeds (powder), T. harzianum + Neem cake, T. harzianum + Melia azedarach, T. hamatum + Neem cake, T. hamatum + Melia azedarach, Bacillus subtilis + Neem cake and Bacillus subtilis + Melia azedarach were used. The fungal antagonists $T$. viride, T. harzianum and T. hamatum in solid form were applied before planting of carnation cuttings at 2 per cent along with Farm Yard manure per bed of $1 \mathrm{~m} \times 1 \mathrm{~m}$ size a week before planting of carnation cuttings of variety ' Rubesco' whereas culture of bacterial antagonists B. subtilis was applied in liquid form (2\%) prepared in sterilized distilled water by dipping of rooted carnation cuttings in this culture for 30 minutes prior to planting. The fungal antagonists (formulated in talc carrier) and bacterial antagonists were procured from Department of Plant Pathology, Dr.Y. S. Parmar University of Horticulture and Forestry, Nauni, Solan.

After treatment, carnation cuttings of variety 'Rubesco' were planted at a distance of $20 \times 20 \mathrm{~cm}$ in $1 \mathrm{~m} \times 1 \mathrm{~m}$ bed with 25 cuttings per bed. Beds without application of any bio-control agent and soil amendment were kept as control. Experiment was conducted in Randomized Block Design (RBD)in year 2012-2013 and each five treatment was replicated thrice. The data pertaining to disease incidence $(\%)$, different plant growth and flower characters were recorded after 10 days of intervals and analysed statistically (Gomez and Gomez, 1983).

\section{RESULTS AND DISCUSSION}

Disease survey: Incidence of stem rot of carnation

Table 4. Impact of integration of bio-control agents and organic amendments on stem rot and growth characters of carnation - pooled data of year (2012-13).

\begin{tabular}{|c|c|c|c|c|c|c|c|c|}
\hline Treatment & $\begin{array}{c}\text { Conc. } \\
(\%)\end{array}$ & $\begin{array}{l}\text { Disease inci- } \\
\text { dence }(\%)\end{array}$ & $\begin{array}{c}\text { Disease } \\
\text { Control } \\
(\%)\end{array}$ & $\begin{array}{c}\text { Plant } \\
\text { height } \\
(\mathrm{cm})\end{array}$ & $\begin{array}{c}\text { Stem } \\
\text { length } \\
(\mathrm{cm})\end{array}$ & $\begin{array}{l}\text { No. of days } \\
\text { taken for } 1^{\text {st }} \\
\text { flowering }\end{array}$ & $\begin{array}{c}\text { No. of } \\
\text { flowers / } \\
\text { plant }\end{array}$ & $\begin{array}{l}\text { Flower } \\
\text { size } \\
(\mathrm{cm})\end{array}$ \\
\hline T.viride+ Neem cake & $1: 1$ & $6.00(2.449)$ & 75.67 & 78.73 & 72.23 & 135.3 & 3.76 & 6.96 \\
\hline $\begin{array}{l}\text { T. viride }+ \\
\text { M. azedarach (SP) }\end{array}$ & $1: 1$ & $6.00(2.449)$ & 75.67 & 82.32 & 76.64 & 131.9 & 3.79 & 7.20 \\
\hline T.harzianum + Neem cake & $1: 1$ & $6.00(2.449)$ & 75.67 & 78.62 & 71.96 & 135.3 & 3.68 & 6.69 \\
\hline T.harzianum + Melia azedarach & $1: 1$ & $12.00(3.464)$ & 51.35 & 76.35 & 70.09 & 142.1 & 3.52 & 6.46 \\
\hline T.hamatum + Neem cake & $1: 1$ & $12.67(3.559)$ & 51.35 & 73.08 & 67.34 & 134.3 & 3.46 & 6.63 \\
\hline T.hamatum + Melia azedarach & $1: 1$ & $12.00(3.464)$ & 51.35 & 74.32 & 67.71 & 134.2 & 3.48 & 6.94 \\
\hline B.subtilis + Neem cake & $1: 1$ & $12.00(3.464)$ & 51.35 & 75.83 & 69.79 & 137.3 & 3.51 & 6.49 \\
\hline B.subtilis + Melia azedarach & $1: 1$ & $8.00(2.828)$ & 67.57 & 81.05 & 75.91 & 133.3 & 3.76 & 7.17 \\
\hline Control & - & $24.67(4.965)$ & & 63.44 & 57.01 & 149.5 & 3.01 & 5.66 \\
\hline $\mathrm{CD}_{(0.05)}$ & & $(0.001)$ & & 1.64 & 2.10 & 1.84 & 0.24 & 0.20 \\
\hline
\end{tabular}

*SP-Seed powder; Figures in parentheses are square root transformed value 
caused by Rhizoctonia solani was recorded during the cropping season of 2012-13 in different carnation growing areas of four districts Bilaspur, Solan, Sirmour and Shimla of Himachal Pradesh. The disease was serious in almost all the locations surveyed however, maximum incidence of the stem rot was recorded at Berthin $(33.7 \%)$ in district Bilaspur followed by Rajgarh (32.0\%), Solan (27.3\%) and Matnali (27.1\%) in district Sirmour in contrast to lowest incidence $(11.2 \%)$ of stem rot in Shimla. The data indicates that incidence of stem rot was comparatively higher in submountainous regions and warmer areas than in the higher hills (Table 1).

Organic amendment: Seed powder of Melia azedarach was found most effective organic amendment which reduced the incidence of carnation stem rot to $15.62 \%$ with maximum disease control of $66-99 \%$ compared to $47.33 \%$ recorded in control. Neem cake was found next in efficacy by giving disease incidence of $24.37 \%$ and control of $48.51 \%$. The amendment of mustard cake resulted in $27.50 \%$ incidence of stem rot followed by amendment with cotton cake (30.0\%) which was found statistically at par. Soil amended with seed powder of Melia azedarach also resulted into maximum average plant height $(56.73 \mathrm{~cm})$, stem length $(49.83 \mathrm{~cm})$, number of flowers per plant (3.33), flower size $(5.95 \mathrm{~cm})$ and required least number of days (145.9) for first flowering compared to control where all the growth characters showed reduction and required maximum number of days (155.0) for first flowering. Different types of soil amendments like oil cakes, composts, residues of crops and others plant products have been found effective in reducing the incidence of different soil borne diseases in different crops. Soil amendments act both on host as well as on pathogens and enrich the soil with beneficial microflora, which are potentially competitive and antagonistic to several soil borne pathogens. These soil amendments also produce various biochemical substances during their decomposition. Besides controlling soil borne pathogens, these soil amendments also improve the soil texture and bring about qualitative as well as quantitative changes in microflora of amended soil (Hortink and Faty 1986). Several workers have studied the qualitative and quantitative changes in the soil amended with different organic and inorganic substances (Bhagyaraj and Rangaswami 1967; Adam et al., 1968; Huber and Watson 1970; Chatopadhyay and Mustafee, 1980; Chandra et al., 1981; Singh et al., 1991). Soil amendment with Neem Kernel Powder (NKCP) controlled Fusarium wilt disease in tomato (Kimaru et al., 2004).

A field experiment was laid out in the polyhouse of the experimental farm during 2012 to know the effect of different potential antagonists on disease incidence, plant growth and flower characters. Two fungal antagonists Trichoderma viride and $T$. harzianum showed superiority over other treatments by recording disease incidence 17.33 and 20.00 per cent in comparison to control $(40.33 \%)$ as both the treatments were found statistically at par with each other. Least effective species among fungal antagonist is $T$. polysporum and among bacterial antagonists Bacillus subtilis resulted in 28.00 per cent reduction in the incidence of stem rot followed by $T$. polysporum $(37.33 \%)$. Among fungal antagonists $T$. viride was found most effective and also resulted in giving maximum average plant height $(71.80 \mathrm{~cm})$, stem length $(65.57 \mathrm{~cm})$, number of flowers per plant (3.53), flower size $(6.24 \mathrm{~cm})$ and required least number of days (133.20) for first flowering compared to control where the plant had on an average significantly shorter plant height $(51.55 \mathrm{~cm})$, shorter stem length $(50.28 \mathrm{~cm})$, less number of flowers per plant (2.35), shorter flower size $(5.37 \mathrm{~cm})$ with maximum number of days (149.67) for first flowering. Singh et al., (2007) reported that treatment of tomato seeds with combination of Trichoderma harzianum and carbendazim resulted in highest disease control (84\%) of $R$. solani in 60 days. Karimi et al., (2007) found strain E121 of Bacillus subtilis and strain E130 of Pseudomonas fluorescens as most effective in inhibiting the mycelial growth of F.oxysporum f. sp. dianthi the cause of wilt of carnation by production of non volatile and volatile metabolites under laboratory conditions.

Dohroo et al., (2012) reported that the effect of soil application of $T$. harzianum bioformulation and rhizome seed treatment with onion and garlic were most potent in limiting the soft rot of ginger.

Integrated disease management: It is evident from data that all the treatments significantly reduced the stem rot incidence over control and also resulted in improvement of the different growth and flower parameters of carnation (Table 4). Integration of Melia azedarach seed (powder) along with Trichoderma viride as well as Neem cake with $T$. viride and T. harzianum individually gave maximum reduction in disease incidence of stem rot with minimum disease incidence $(6 \%)$, in comparison to control $(24.67 \%)$. All the three treatments were significantly at par in their efficacy and showed superiority over other treatments with respect to plant health parameters. Rehman and Lawrence (2010) used two fungal antagonists viz., Trichoderma viride and Trichoderma harzianum along with fungicide carbendazim as seed treatment and soil drench and found significant inhibition in growth of Rhizoctonia solani in cabbage.

However, among Trichoderma spp. T. viride, T. harzianum, T. hamatum and neem cake combination recorded high incidence (12.67\%) compared to superiority with respect to plant growth and flower quality parameters. However, the average plant height $(82.32$ $\mathrm{cm}, 81.05 \mathrm{~cm})$, stem length $(76.64 \mathrm{~cm}, 75.91 \mathrm{~cm})$, number of flowers per plant $(3.79,3.76)$, flower size 
$(7.20 \mathrm{~cm}, 7.17 \mathrm{~cm})$ were maximum in treatments, $T$. viride + Melia azedarach and B. subtilis + Melia azedarach, respectively. Similarly, number of days to first flowering was less in these combinations as days to first flowering reduced to 18 days compared to control where no addition of biocontrol agents and soil amendments in soil was done thus indicating their possible use in checking the disease as well as mitigating the losses by improving the plant health. Application of neem cake in combination with $T$. viride resulted in the highest control of Fusarium yellows in gladiolus among different combinations of organic amendment and biological control agents while the combination of neem cake and T. harzianum proved better in increasing corm yield (Sharma, 2001). Dipping of gladiolus corms in Quintal $(0.25 \%)+$ soil amended with cabbage leaves in solarized soil resulted in increase shoot length, spike length, corm size compared to control (Raj and Upmanyu, 2006).

\section{Conclusion}

A huge quantity of chemicals are used to reduce the ravages of various diseases which are not only detrimental to the environment but are also hazardous to the human health and needs to be replaced by less detrimental compounds preferably from natural sources. The biological control aims at eradication or management of pathogens through the activity of other microorganisms. It can be carried out either by manipulating the existing soil microflora to the disadvantage of the pathogen or by addition of non-resident antagonists (Cook, 1982). Keeping in view the economic importance of the research gaps and meagre information available in literature on different aspects, it was thought worthwhile to investigate the stem rot disease of carnation by using ecofriendly approaches. Integration of Melia azedarach seed (powder) along with Trichoderma viride as well as Neem cake with $T$. viride and $T$. harzianum gave maximum reduction $(75.67 \%)$ in disease incidence of stem rot with minimum disease incidence $(6 \%)$, in comparison to 24.67 per cent in control followed by Bacillus subtilis + Melia azedarach (8\%).

\section{REFERENCES}

Adam, P.B., Papavizas, G.C. and Lewis, J.A. (1968). Survival of root- infecting fungi in soil. Phytopathology, 58: 373-377.

Bhagyaraj, J. and Rangaswami, G. (1967). Effect of fertilizers on the microflora of soil and rhizosphere of ragi (Eleusine coracana). Indian Journal of Microbiology, 7: 29-38.

Chandra, S., Raizada, M. and Khanna, K.K. (1981). Effect of organic amendments on the rhizosphere microflora of tomato. Proceedings of the Indian Academy of Sciences, 90: 189-197.

Chatopadhyay, S.B. and Mustafee, T.P. (1980). Influence of organic amendments on the growth of soil inhabiting fungal pathogens. Indian Journal of Microbiology, 18:
69-70.

Cook, R.J. (1982). Progress toward biological control of plant pathogens with special reference to take all of wheat. Agric. For. Bull. 5: 22.

Dohroo, N.P., Kansal, S., Mehta, P. and Ahluwalia, N. (2012). Evaluation of eco-friendly disease management practices against soft rot of ginger caused by Pythium aphanidermatum. Plant Disease Research, 27(1):1-5.

Evans, A. (2008). http://www. Floraculturalinternational. com.

Gomez, K.A. and Gomez, A.A. (1983). Statistical procedure for agriculture research. Jonn Willey and Sons, New York, 680 p.

Hortink, H.A. and Faty, P.C. (1986). Basis for the control of soil borne plant pathogens with composts. Annual Review of Plant Pathology, 24: 93-114.

Huang, H.C. and Hoes, J.A. (1976). Penetration and infection of Sclerotinia sclerotium by Coiniothyrium minitans. Canadian Journal of Botany, 54: 406- 410.

Huber, D.K. and Watson, R.D. (1970). Effect of organic amendments on soil-borne plant pathogens. Phytopathology, 60: 22-26.

Karimi, E., Rouhani, H., Zafari, D., Khodakaramian, G. and Taghinasab, M. (2007). Biological control of vascular wilt disease of carnation caused by Fusarium oxysporum f. sp. dianthi by Bacillus and Pseudomonas strains isolated from rhizosphere of carnation. Journal of Science and Technology of Agriculture and Natural Resources, 11: 309-320.

Kimaru, S. K., Waudo, S.W., Monda, E., Seif, A. A. and Birgen, J.K. (2004). Effect of neem kernel cake powder (NKCP) on Fusarium wilt of tomato when used as soil amendment. Journal of Agriculture and Rural Development in the Tropics and Subtropics, 105: 63-69.

Kurzawinska, H. (2008). Reports of plant diseases. New York State Horticulture Society 70:23-29.

Raj, H. and Upmanyu, S. (2006). Solarization of soil amended with residues of cabbage leaves and corm treatment with fungicides for management of wilt (Fusarium oxysporum) of gladiolus (Gladiolus grandiflorus). Indian Journal of Agricultural Sciences, 76: 307-311.

Rehman, S.U. and Lawrence, R. (2010). Biological control of Rhizoctonia stem canker and black scurf of potato. Phytopathology, 75: 560-564.

Rini, C. R. and Sulochana, K.K. (2007). Management of seedling rot of chilli (Capsium annum L.) using Trichoderma spp. and fluorescent pseudomonas (Pseudomonas fluorescens). Journal of Tropical Agriculture, 44: 79-82.

Sharma, S.N. (2001). Studies on biological control of Fusarium yellows of gladiolus. M. Sc. Thesis, Dr. Y S Parmar UHF, Nauni, Solan (HP), India, 63p.

Singh, C. B., Shipra, S., Preeti, J. and Yadav, F. D. (2007). Eco-friendly management of vascular wilt of solanaceous vegetables. Flora and Fauna Jhansi 13: 98-100.

Singh, K.P., Bihari, K. and Singh, V. K. (1991). Effect of culture filtrates of fungi colonizing neem cake on Heterodera cajani. Current Nematology, 2: 9-14.

Tripathi, P., Dubey, N. K. and Shukla, A.K. (2008). Use of some essential oils as post-harvest botanical fungicides in the management of grey mould of grapes caused by Botrytis cinerea. World Journal of Microbiology and Biotechnology, 24: 39-46. 